\title{
THE TAX CALENDAR AND THE USE OF INSTALMENT PAYMENTS, PENALTIES AND DISCOUNTS
}

\author{
JENS P. JENSEN*
}

It may be said in advance that any reform in the mechanics indicated in the title of this article is not likely to prove a major remedy for property tax delinquency. But the same may be said of any other possible property tax reform proposal. Delinquency is in itself an evil; but it is also a symptom of more basic maladjustments. It will have to be attacked in more than one way. However, the suggestions here made have merits on other grounds than mere prevention of delinquency. ${ }^{1}$

\section{The Calendar}

Despite variations among them, the property tax calendars of the several states bear a family resemblance to each other. They were developed with certain requirements in mind, which were fundamentally the same in all the states. They grow out of the function assigned to the property tax in all the states. This tax is a deficiency tax, raising whatever sums are required by the local governmental budgets, and to a diminishing degree the state budgets, after the deduction of the revenue expected from other sources. The fact that this tax, for most local governments at least, furnishes nearly all of the revenue, does not minimize the use of the tax as the elastic element in the local and state tax systems.

The functions which the calendar is designed, or has been developed, to serve are simple enough in principle. First, the taxable property is to be assessed, a process

- A.B., I9r3, Dakota Wesleyan University; M.A., 1917, University of Minnesota; Ṕh.D., 1926, University of Chicago. Professor of Economics, University of Kansas, teaching courses in Public Finance and Taxation. Author of Public Finance (1924); Survey of Colorado State Tax System (1930); Property Taxation in the United States (193I); (With Harald Howe) Tax Study in 13 Lessons (1932); Survey of Bank Taxation (for American Bankers Association) (1929, 1931, and 1935). Contributor to Tax Systems of the World, Tax Research Foundation, and to The American Year Book (articles on "Property Taxation" and "Corporation and Bank Taxation"). Author of numerous other articles in periodicals in the field of economics and taxation.

${ }^{2}$ It is not attempted in this article to describe in detail the actual status of the several states in the matters treated. Attention is drawn to the following sources, among others, to which indebtedness is hereby acknowledged: Hunter, Legal Provisions Affecting Real Estate Tax Delinguency, Tax Sales, and Redemption (1933) Bull. No. 48, Bureau of Business Research, Univ. of Illinois; Jensen, Property Taxation in the Unted States (I931); National Industriat Conference Board, State and Local Taxation of Property (1930); Tax Research Foundation, Tax Systems of the World (6th ed. 1935 ). 
which is nothing more than the determination of the quantity and value thereof. Strictly speaking, only the value is required, since the tax is ad valorem. If the original assessment were acceptable to the taxpayers, only one more function would be required, namely, the extension of the tax on the valuation. Because the original assessment is faulty, or is deemed so by at least some of the taxpayers, several supplementary functions are required. Second, the calendar makes room for the local review, developed to iron out errors and inequalities among individual taxpayers: Third, the calendar must make room for an equalization among the political units, towns or counties, and among classes of property, to eliminate possible discriminations. Fourth, upon the roll, thus presumably corrected, the tax must be extended for every owner of taxable property in the county or town. Fifth, the calendar must as a practical matter provide for a waiting period, between the date when the taxes are due and the date on which they become delinquent, for the obvious reason that the payment requires time. At this point, as far as the taxpayer is concerned, the calendar might stop, if all went by the card, if all taxes were paid on or before the delinquent date. The fact that they are not all paid then, necessitates an extension of the calendar to provide for dates of sale, redemption, penalties, interest, and final granting of title to delinquent property. In this article, however, the attention is limited largely to the five parts of the calendar described above, the balance being treated in other articles in this volume.

In its relation to property tax delinquency, the calendar may be considered from three angles. First, most of the calendars are too long. They consume too much time between the assessment date (the date as of which the assessment takes effect) and the delinquency date (the date after which interest and penalties become effective). It is true that criticism of the calendars in some of the states may also arise because they do not adequately provide for all of the five essential steps in the procedure outlined above, by not providing, for example, for adequate local review or state equalization. And such omissions may produce poor assessments, which in turn may react unfavorably on the collection. But too long a calendar lengthens the time between the day when the tax becomes a lien on the property and the day on which it becomes delinquent. In this interval many things may happen to the property, especially in case of personal property, and to the taxpayer, rendering him unable or unwilling to pay the tax.

Implicit in the long tax-determination interval is the assumption that the tax, once levied, is safe for the treasury, because of the lien on the property. Relying upon this safety, the administration could proceed by leisurely stages, and protect itself by interest and penalties high and heavy enough to reimburse it for interest paid on money borrowed to offset the deferred payment or non-payment of delinquent taxes. But the lien is in fact not safe, on any class of property. Taxes on personal property, tangible as well as intangible, remain unpaid in large amounts because the property, present at the assessment, has been moved away before the delinquent day. Real 
estate may be "skinned," by removing timber or minerals during the interval; laws making such skinning illegal are difficult to enforce, and in any case touch only the most obvious cases. Even in case of land and fixtures, the value, the essence of property for purposes of taxation, may vanish, as is all too frequently demonstrated in the taxes unpaid. Shortening the tax-determining interval would reduce these hazards to the tax lien.

The characteristic interval between the tax day and the delinquent day is 10-14 months, but the spread is wide on both sides of a norm of about II months. There is considerable opportunity for shortening the interval, as indicated by the fact that several states run as low as eight months. - In those states which permit instalment payments, where the interval between the first and second payment is usually six months, the second half of the tax will not be payable until 15 to 20 months after the day as of which the tax liability attached to the property.

What is a reasonable interval for the determination of the tax liability of individual taxpayers, with respect to particular parcels of real property? If two months be allowed for the assessment, one for the local review, one for the preparation of the abstract for delivery to the state board of equalization, two for the state equalization, two for the extension of the taxes on the roll, and one for payment prior to the delinquent date, all the necessary' functions of the tax-determination process would seem to be allowed for, and the total time amount to only nine months. This happens to be about the interval used in Wisconsin, and would seem to be ample, if the frills be eliminated. A number of states do the job in less time.

In the second place, although of less importance, it may be asked whether the interval, whatever it be, begins and ends at the most advantageous point in the seasions. Historically this factor has been important. Of the eight states in the southern tier of states, five begin their calendar with the assessment of January I; one, of February; another, California, of March, while Alabama begins the year, "the year before," as of October I. In contrast, of the II states in the northern tier, five begin on April I and four on May I, the two nonconforming states preferring July and January, respectively. In the choice of these beginning dates, it was of weight that they marked the season when in an agricultural economy there would be no crops and, in short, a minimum value. The assessor, who was likely to be a farmer, would have time for the assessment; and in rough areas he would be able to "get around" relatively unimpeded by winter weather. In the choice of the delinquent dates, it was desirable that they should fall at a season when the taxpayer 'would likely be "in funds." Undoubtedly these factors are of less weight now. -Particularly, it is difficult to find a season when the dominant class is in funds, all the more so where instalment payment is permitted.

In the third place, the calendar may be ill-proportioned, allowing improper time for the various functions, or it may be loaded with unnecessary details and processes which have gotten themselves imbedded in the system. For example the practice 
of several states, chiefly in the south, of self-assessment appears to be a relatively useless procedure which, nevertheless, it would be difficult to remove. It probably saves very little time for the assessor when he comes to go after the items that have not been rendered voluntarily. It may of course be said that, say, two months spent by the assessor in receiving voluntary renditions of property are merely a sort of preliminary to the assessment; but they are really a part of it since they widen the interval between the tax day and the delinquent day.

But it would be foolish to place much faith in the shortening of the tax-determining interval as a remedy for delinquency so long as the present function of the property tax as a deficiency measure prevails. If the tax liability must be determined completely, barring resort to the courts on matters of law, and by a long and involved process as at present, before any tax payment is required, then the ultimate minimum of time required can not be much less than, say, eight months. If, instead of being an apportioned tax, calculated to raise any necessary amount, it were to become a percentage tax, with the rates stated in the law rather than to be computed as at present, then the property owner might be required to file a return, and remit payment with return, thereby materially shortening or eliminating the tax-determining interval, as is the practice in the administration of the personal income tax. Any one at all familiar with fiscal organization and administration will realize that such a shift would require changes at innumerable points other than in the procedure of assessment and tax collcction.

Making the property tax a percentage tax would doubtless facilitate collection and reduce detinquency, once it were in working order. But as a matter of reform solely in the interest of better collection, such a shift would not be wise. On the other hand, if tax limitations continue to be adopted to restrict the tax rate below or on the stated limit; if new sources of revenue continue to be found; if state assumption of hitherto local functions and state equalization of educational and other hitherto local governmental costs are extended, the property tax will in effect be a percentage tax, and only in form an apportioned tax. To change the form to correspond to the real character would not then be very difficult. In such an event, the shortening, or the elimination, or the deferring of the final tax determination until after the initial tax payment would, it may be safely predicted, facilitate the collection and reduce the delinquency. But this condition is a long way from being realized.

\section{Instalment Payments}

It seems hardly necessary to argue that property taxes should be paid or at least payable in instalments, rather than in one annual lump sum. But here again, the practice must be defended mostly on other and broader grounds and only to a small extent on the ground of preventing delinquency, although it will undoubtedly have the effect of collecting a larger percentage of the taxes levied. The only argument that can be made against instalment payments is the probability that the cost of 
collection will be slightly increased, although it may be expected that the increased collections to be expected will more than overcome this loss. Some sort of estimate of the increased cost of instalment payments could probably be had from states permitting instalments, particularly from those which have recently made the change from an annual to an instalment basis. As far as the writer is aware, no such studies have been made, at least of an extended scope. This same may be said of the increases in the collections that might be expected from allowing instalments.

From the treasury point of view, aside from the increase in the collections to be expected, instalment payments smooth out the stream of revenue flowing into the treasury, and thereby tend to eliminate alternating heavy treasury balances and deficiency borrowing. They also tend to render the payment of the property tax less odious. At present, on this point, it suffers by comparison with sales taxes, in which the payment is concealed. From the taxpayer's point of view instalment payment would be desirable because of the deferment of the payment. The only class of taxpayers to whom lump-sum annual payment is advantageous is composed of those whose property-tax due date happens to coincide with the date of a relatively large receipt of disposable cash. For obvious reasons, this class must be small. In view of these undoubted net advantages of instalment payments, the fact that about one-half of the states still require payment once each year only, is strong evidence of inertia.

\section{Penalties and Interest}

It is obvious that taxes can not be collected without penalties in the present form of "society. It is also obvious that these penalties may assume a great diversity of form, serving more or less effectively the purpose of compelling payment on or before the delinquent date. It may be, but rarely is, solely in the form of a flat rate on the amount delinquent, as 10\% in Arkansas. This form may stimulate payment on or before the due date; but since the penalty does not increase after that date with continued non-payment, it must operate to encourage non-payment until just before the sale of the property for the tax. The penalty may be in the form of interest, beginning at the delinquency date, as in case of Arizona, Nebraska and New Hampshire, where the rate is 10\% per annum, until the tax is paid or the property is sold. This form provides no special inducement to pay exactly on the due date, but does provide a continuing pressure to pay as soon as possible or convenient. The initial rate of interest may be changed as the delinquency period lengthens. And the flat penalty and the continuing interest may be combined into a great variety of forms. A similar effect may be had by allowing an abatement or a discount for prepayment or for payment before a specified date. Where instalment payments are permitted, the entire amount may become due and delinquent if the first instalment is not paid on or before the due date. The possibility for combinations may be imagined. The penalty system is apparently not identical in any two states. 
What is not so obvious is the fact that, although penalties in some form and of some weight are inevitable, the particular level and form of the penalty does not seem to be a major factor in the efficiency of the collection system. The percentages of delinquency vary widely between localities within the same state and therefore subject to the same penalties. Whether very severe and involved systems of penalties stimulate tax payment materially is doubtful, but in many cases they certainly do not. If the owner is without funds and without credit, it makes very little difference what the penalties are. If the property is overassessed or if the value shrinks so that it seems the more desirable alternative to let the property "fly for taxes" rather than to pay the tax and continue the enjoyment of or income from the property, no amount of penalties will induce the payment of the tax. And it is probable that the overwhelming share of all delinquency is due to one or both of these causes.

It ought to follow therefore that the penalty system need not be very severe or very complicated. Yet there seems to be merit in providing not only an incentive to payment before the delinquent date but also a continuing inducement to payment after that date. This double requirement may be met by a combination of a moderate lump-sum penalty and a moderate rate of interest, both becoming applicable on the delinquent date. Such a system is exemplified by the Michigan system, with a slight variation, of a $4 \%$ penalty (collection fee) applicable on January ro, plus $3 / 4$ of $x \%$ per month from March I. A similar system is that of Wisconsin, in which state there is a $2 \%$ penalty as of February 1 , and an interest of $1 \%$ per month, the maximum interest to be $8 \%$. The effect of these combinations is to make the penalty (penalty and interest) regressive with the length of the delinquency, which seems proper. The variations in the penalty systems indicate that the philosophies on which the penalties are based arc often at variance with the one just suggested.

The question may be raised as to the proper severity of both the penalty and the interest. It would be presumptious to set up rates for these figures to be applied throughout the country, for the rate of interest and other pertinent factors differ from state to state. The rates should be set with two principal considerations in mind: First, to hold the treasury reasonably undamaged from the delinquency, but not to derive revenue from a misfortune befalling its citizens-taxpayers; second, to provide an inducement adequate to stimulate taxpayers in funds or in credit to pay their taxes promptly rather than, in effect, to borrow money from the treasury, by deferring the tax payment. The level of the penalty and interest rates required by these two considerations will have to be found by experience. It seems that neither of these considerations, or both of them together, could have dictated some of the existing penalty systems. There seems, for example, to be no reason for Nevada's system which consists of the flat penalty of $15 \%$, plus interest at the rate of $3 \%$ per month, both applicable to the amount unpaid on the delinquent date.

Whatever the form and level of the penalty scheme, one thing should be clear. The penalties will be ineffective if they are to be withdrawn, as they have been 
during the depression of 1929 , whenever the property tax becomes hard to pay. Some other method of giving relief to such as may be deserving thereof should be devised. A general withdrawal of penalties benefits deserving and undeserving alike, and damages both alike through the detriment to the public services, which the fiscal chaos of such remissions produce. It may be that the political pressure for relief in such cases is too strong for most legislatures to resist. If so, we have here an insoluble problem in property taxation. For hard times are, of all times, the times when the penalties ought to work. But this problem will be treated in another article of this volume. ${ }^{2}$

\section{Discounts}

The practice of allowing discounts for prompt payment, for payment before a specified date, after the due date, or for prepayment before the due date was extended by some of the states as a result of the depression, since r929. These ventures are mostly experimental; some of them were dictated by the emergency, and were probably unsound. The following types may be distinguished:

First, the local and optional discounts. In four of the New England states it is optional with the towns to order or to vote discounts within statutory limits. This form of discount is rare elsewhere; and its purposes are not obvious.

Second, in Kansas a $2 \%$ discount may be allowed on the second half of the tax if it is paid on or before December 20 , the delinquency date for the first half. It is difficult to see the justification for this device. It is advantageous to the taxpayers with money, for whom the discount amounts to an absolutely safe and tax-free investment at $4 \%$ for six months. These taxpayers would not become delinquent anyway. As for the treasury, the effects are dubious. It is well that it has not spread far.

Third, in Florida, North Carolina, Oregon, and Utah a scheme of discounts for prepayment and prompt payment has been adopted, which, in so far as it is actually used, may advance the payments to a date much nearer the assessment date, and is so far to the good. In North Carolina, for example, the assessment day is April $\mathrm{r}$. Having completed the standard steps in the calendar, the taxes become due on the first Monday in October, and delinquent on the first day of February: If paid on or before November I, a discount of $x \%$ is allowed; if paid after November $I$ and on or before December $x$, the discount is only $1 / 2$ of $x \%$; and payments made thereafter but not after the delinquent date are made at par. These discounts on payments made between the due date and the delinquent date are the customary discounts for "prompt" payment. They can be made in the exact amounts due, since the taxes have already been extended prior to the due date. But prepayments may be made on or before July $\mathrm{x}$, with a discount of $3 \%$; and thereafter until the due date, with the discount declining by $1 / 2$ of $\mathrm{r} \%$ for each month. The prepayments must be made in tentative amounts, since the exact rate and amount of the tax is not known at

'Sce Smith, Recent Legislative Indulgences to Delinquent Taxpayers, infra, 371, at p. 372. 
that time. The results of this prepayment scheme are unknown to the writer of this article.* On the face of it, the scheme possesses possibilities, on the one hand, for spreading the payments over the year, and, on the other hand, for bunching them at points in the season inconvenient to the treasury, since both prepayment and "prompt" payment are optional with the taxpayers. This optional feature may be convenient to the taxpayers who wish to pay when they are in funds. It also, like the Kansas scheme, provides a safe, tax-free investment, in North Carolina at the rate of something less than $6 \%$. The scheme invites the suggestion that it might be a transition to the practice of making payments tentatively with the return, as suggested above in this article, in other words, to the conversion of the property tax into a percentage tax.

- Edrtor's Note: At Professor Jensen's suggestion, an inquiry was made with reference to North Carolina experience under its prepayment scheme. The following statement was obtained from Mr. Henry Brandis, Jr., Associate Director of the Instinte of Government at Chapel Hill, North Carolina, who has been making a study of property taxation in this state.

"The reason for the discounts allowed prior to the due date in North Carolina is found in the fact that, while the due date is the first Monday in October, the fiscal year begins on July r. . The discount system is designed to bring in enough money to allow the counties and cities to operate during the first three months of the fiscal year without anticipatory borrowing with its potential deficit dangers. From the standpoint of the units themselves it certainly served a useful purpose as long as most of them (many being in default) could borrow nothing from the banks or could borrow only at $6 \%$. Under present conditions many of our units either carry over enough cash or immediately collectible delinquent taxes to enable them to finance a large part of first quarter operations or can borrow money at far less than $6 \%$. At least one of our soundest units has, for many years, budgeted enough each year to take care of the first three months of the next fiscal year. We still have a number of units which find the discount a desirable and even a necessary aid to first quarter fnancing; but those finding it expensive financing are beginning to doubt its merits, and it may well be that it will eventually be placed on a local option basis. Turning to its effect on tax delinquency, we can safely say: (I) that it has been chiefly used by large personal and corporate taxpayers who see in it, particularly under present conditions, an investment representing a certain and comparatively high return; (2) it obviously can be of no great help to that class of taxpayers who do not have money available before autumn and whose credit facilities are not great; and (3) it has not prevented tax delinquency, but, in view of the fact that in some industrial centers as high as a third of the total levy is sometimes collected prior to the due date, it must have some tendency to reduce tax delinquency by substizuting a certainty for a possibility. In the main those who prepay could and would pay promptly otherwise. In its other aspects the discount system has: ( $I$ ) been a minor complicating factor in the making of budgets; and (2) caused considerable bookkeeping trouble in cases in which the final tax rate varies from that estimated at the time the prepayment is made. This last factor varies greatly with the individual unit. In a number of cases the rate is estimated correctly, even as early as July $I$. When it is originally estimated incorrectly the actual rate is usually known for some time prior to October 1 . So far as most taxpayers are concerned valuations have already been finally fixed by July' I, and, while it is frequently troublesome to consult the valuation records, the valuation is seldom changed after the prepayment has been made." 